\title{
Pengaruh Arsitektur Tradisional Jawa dalam Hunian Kolonial di Kampung Bubutan Surabaya
}

\author{
Risqi Cahyani, Lisa Dwi Wulandari, Antariksa \\ Program Magister Arsitektur Lingkungan Binaan, Universitas Brawijaya Malang \\ qqcahyani@gmail.com
}

\begin{abstract}
ABSTRAK
Kampung Bubutan merupakan salah satu permukiman penduduk asli di Kota Surabaya. Sebagai kota pesisir, Surabaya lekat dengan image sebagai kota perdagangan. Faktor ini menyebabkan banyak pendatang yang berasal dari berbagai budaya termasuk budaya asing salah satunya Belanda. Artikel ini akan membahas tentang apa yang mempengaruhi pola permukiman kampung Bubutan, dan bagaimana akulturasi budaya antara Jawa dan Kolonial pada hunian di kampung Bubutan dengan menggunakan metode kualitatif-deskriptif. Hasil pembahasan adalah bentuk sungai Kali Mas dan mitos Mancapat berpengaruh pada bentuk pemukiman di sekitar kampung Bubutan. Pengaruh arsitektur kolonial pada bangunan ditemukan pada bentuk dasar dan teknologi bangunan. Sedangkan pengaruh arsitektur Jawa ditemukan pada ornamen bangunan, organisasi ruang yang mewadahi aktivitas penghuni, dan pemaknaan manusia yang menghargai; alam nusantara dan peran sosial masyarakatnya. Nilai-nilai, petuah, dan pitutur bijak budaya Jawa menjiwai pemaknaan pada bangunannya.
\end{abstract}

Kata kunci: budaya Jawa, arsitektur kolonial, akulturasi budaya

ABSTRACT

Kampung Bubutan is one of the original community of settlements in the city of Surabaya. As the coastal city, Surabaya closely with the image as a trading city. These factors led many immigrants come from many different cultures, local and international including Netherlands. This article will discuss about what makes the formation of the settlement pattern at Kampung Bubutan, and how the acculturation between Javanese and Colonial on the settlement using descriptive-qualitative method. The results is Kali Mas river and Mancapat mythe effected the formation of Kampung Bubutan settlements. Colonial architectural found in the basic shape of the building and building technology. While the Javanese architecture found in the building ornaments, organizations of space, and the meaning of the Javanese who appreciate nature and social community. Values, advices, and good wises from Javanese giving much meaning in the house.

Keywords: Javanese architecture, colonial architecture, etnic aculturation

\section{Pendahuluan}

Kota Surabaya mengalami beberapa fase historikal dimulai dari masa pengaruh kerajaan Majapahit, kemudian menjadi kota Kolonial, hingga sekarang menjadi kota metropolitan. Pengaruh budaya Jawa pada abad 14 menjadi titik awal terbentuknya kawasan kota ini [Darjosanjoto, 2005]. Sungai Kali Mas memiliki peran sebagai sarana transportasi air dalam tradisi perdagangan. Jembatan Merah merupakan pelabuhan tradisional tempat berlabuhnya perahu dan tongkang. Sehingga Arah tren arus pedagangan di Surabaya berawal dari arah utara (pelabuhan) menuju ke selatan (tengah kota) dan sebaliknya.

Pada masa pemerintah Hindia Belanda abad ke-17 mulai dibangun infrastruktur jalan yang mengikuti pola aliran sungai Kali Mas. Pola jaringan jalan ini erat kaitannya dengan pola arah perdagangan di Surabaya pada saat itu yang menggunakan 
transportasi sungai yaitu dari arah utara ke selatan [Handinoto, 2006]. Hingga kini jalan tersebut menjadi jalan arteri kota yang mempengaruhi pola permukiman masyarakat Surabaya. Pada tahap terbangunnya infrastruktur jalan darat, bersamaan pula tumbuh bangunan kolonial yang berfungsi sebagai bangunan perdagangan dan pemerintahan. Bangunan di sepanjang jalan arteri dimiliki oleh warga Belanda, sementara warga pribumi bermukim di balik jalan besar dan membentuk perkampungan milik pribumi. Gaya arsitektur Kolonial milik warga Belanda ini mempengaruhi gaya arsitektur rumah orang pribumi. Pada saat itu muncul anggapan bahwa rumah orang yang berstatus sosial tinggi dan ideal adalah rumah bergaya Kolonial, seperti yang diceritakan dalam Serat Balewarna oleh Mas Sastrosudirjo seorang mantri guru dari sekolah orang pribumi di jaman Belanda [Prijotomo, 2002]. Bagian utara kota banyak dijumpai permukiman kuno denga gaya arsitektur kolonial. Semakin ke arah selatan kota, gaya bangunan permukiman penduduk kota semakin modern.

\section{Bahan dan Metode}

\subsection{Tinjauan Pustaka}

Akulturasi budaya terjadi ketika pendatang masuk dengan membawa nilai dan unsur budayanya yang kemudian bercampur dengan kebudayaan lokal. Akulturasi budaya mempengaruhi arsitektur lokal melalui ragam, pola ruang, dan tatanannya, sehingga hasil percampuran budaya akan membentuk citra baru masyarakat lokal [Fauzy, 2012]. Pemaknaan sebuah bangunan dilihat dari kacamata budaya, akan dipersandingkan dari dua aspek sudut pandang yaitu adat istiadat/budaya dan bentuknya, Koentjaraningrat [1981]. 'Adat istiadat' yang dimaksud adalah mencakup ide, gagasan, norma, nasehat, pitutur yang bersifat abstrak yang merupakan sistem sosial masyarakat. Sedangkan 'bentuk' yang dimaksud adalah wujud fisik dari kebudayaan itu yang bersifat konkret. Nilai-nilai kearifan lokal yang terkandung dalam konsep budaya Jawa merupakan hasil dari representasi hubungan manusia dengan Tuhan, manusia dengan alam, manusia dengan manusia sebagai makhluk sosial, manusia sebagai pribadi individu.

Pada budaya Hindu Jawa, dikenal empat penjuru mata angin sebagai arah orientasi yang masing-masing bernaung dewa-dewa (mitos Mancapat) sebagai unsur keseimbangan kosmologis budaya Jawa [Ronald, 2005:38]. Orientasi rumah masyarakat Jawa umumnya memakai sumbu kosmis Utara-Selatan, sedangkan Timur-Barat adalah sumbu kosmis milik bangsawan dan keraton yang harus dibedakan menurut Frick [2010: 84-85]. Di Selatan diyakini sebagai tempat tinggal penguasa laut selatan dan di Utara diyakini bermukim dewa Wisnu sebagai pelindung kerajaan Mataram. Di Timur diyakini sebagai tempat bermukim dewa Yamadipati (dewa kematian). Arah orientasi yang benar dipercaya akan mendatangkan keberuntungan dan kebahagiaan, begitu juga sebaliknya apabila tidak tepat, akan mendatangkan kesialan, kesakitan, dan kesedihan.

Rumah Jawa terdiri dari beberapa massa [Prijotomo, 1999], antara lain:'Griya Regol' , gapura, gerbang masuk, maknanya yaitu tatakrama antara yang tua ke yang muda, yang kecil ke yang besar. 'Griya Wingking', omah mburi, bangunan pemilik rumah. 'Griya Ngajeng', pendopo, omah ngarep. 'Griya Pawon', dapur. 'Griya Ghandhok', bangunan tambahan, lumbung, kandang. 'Gedhogan', kandang kuda. 'Pagongan', bangunan untuk memainkan gamelan. 'Pringgitan', bangunan antara griya ngajeng dan griya wingking. 'langgar','sanggar pamujan', tempat sembahyang. Rumah joglo pada konsep awalnya memakai material kayu pada struktur dinding dan atapnya. Pemakaian dinding satu bata pada rumah jawa merupakan pengaruh arsitektur Kolonial yang merupakan representasi tingkat sosial ekonomi. 


\section{$2.2 \quad$ Metoda}

Penelitian ini merupakan penelitian Rasionalistik, berawal dari tinjauan pustaka yang kemudian dicocokan dengan kondisi fisik pada studi kasus yang menggunakan metode Kualitatif. Pembahasan meliputi telaah pola pemukiman kampung dan telaah pada makna rumah. Pembahasan pada rumah terdiri dari dua tahapan, yaitu pertama, menganalisa komponen fisik bangunan sebagai unit amatan ditinjau dari Arsitektur Jawa dan Arsitektur Kolonial. Tahapan kedua, yaitu mencari pemaknaan dari budaya Jaw yang lebih mendalam pada rumah.

Hasil dari penelitian akan berkembang selama proses penelitian berlangsung. Proses dan hasil penelitian diungkapkan secara Deskriptif untuk menjelaskan dan menggambarkan hasil unit amatan di lapangan. Studi kasus mewakili tipe bangunan Voor 1900 [Nix, 1994] yang merupakan tipe terbanyak yang ditemukan di kampung Bubutan.

\section{Hasil dan Pembahasan}

\subsection{Telaah Pola Permukiman}

Pola permukiman dibahas melalui dua pendekatan yaitu pendekatan historikal dan pendekatan mitologi budaya Jawa. Sejarah pembentukan kawasan ini tidak terlepas dari karakternya sebagai kota dengan tradisi perdagangan yang terjadi sejak jaman kerajaan Majapahit. Bentukan alamiah sungai Kali Mas menjadi acuan pola jalan arteri kota. Pola jaringan jalan tersebut mengikuti tren perkembangan perdagangan yaitu dari arah Utara (pelabuhan) ke arah Selatan (tengah kota). Jaringan jalan arteri ini menjadi kerangka terbentuknya permukiman penduduk pribumi yang menempatkan dirinya di balik jalan arteri. Pendekatan historikal ini yang menjadi dasar terbentuknya jalan arteri kota Surabaya (Gambar 1).

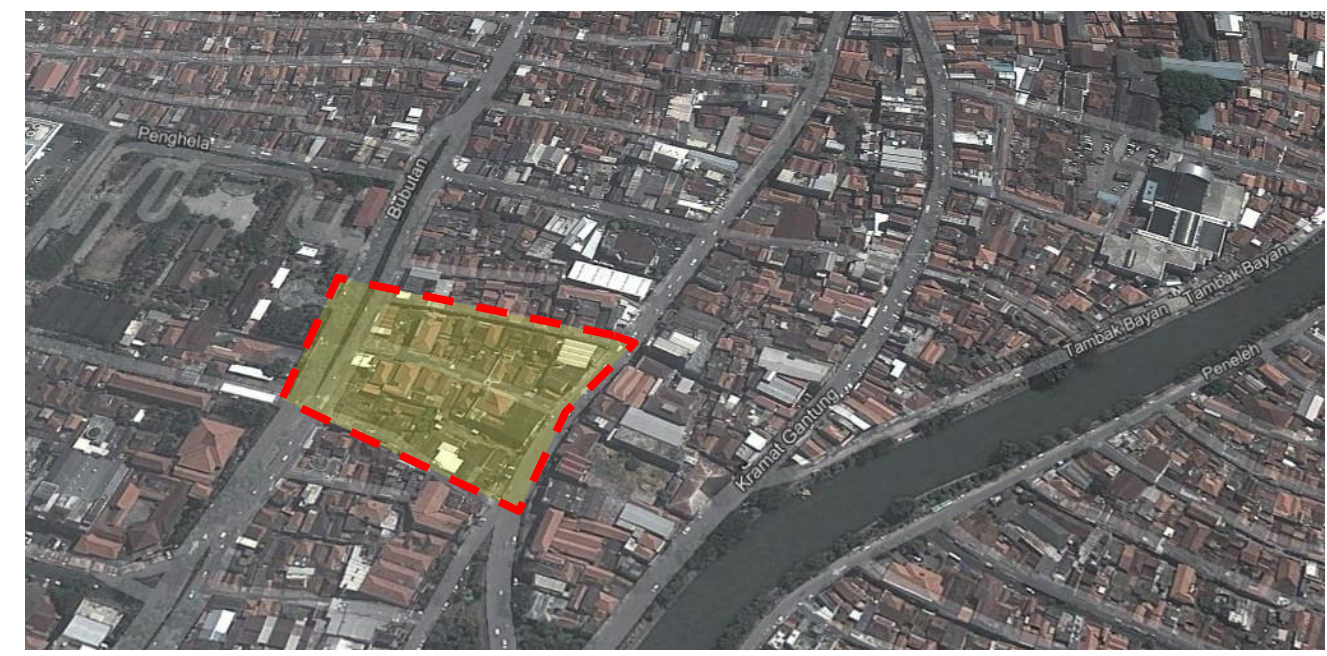

Gambar 1. Pola jaringan jalan arteri kota dari arah utara ke selatan (Sumber: google earth 2014)

Ditinjau dari teori kosmologi Jawa bahwa manusia secara kodratnya memiliki hubungan dengan alam. Hamemayu Hayuning Bawana dan sumeleh / Pasrah merupakan pemaknaan dari nasehat Jawa yang diterapkan pada arah hadap rumah tinggal tradisional. Rumah yang membawa kesejahterahan penghuninya sepatutnya menghadap ke arah Utara dan Selatan, karena di Utara bermukin dewa Wishnu sang pelindung kerajaan Mataram. Kampung Bubutan pada abad ke-15 merupakan kawasan keraton Surabaya yang merupakan bagian dari kekuasan kerajaan Mataram Widodo, D. [2013:77] dan Soenarjo [2006:18-19]. Arah Selatan dipercaya terdapat kekuatan yang 
sangat berpengaruh yaitu penguasa laut selatan, Nyi Roro Kidul. Hal ini adalah bentuk tunduknya manusia terhadap alam. Pitutur jawa lainnya yaitu Tepa Slira dan Rukun agawe Santosa merupakan pemaknaan yang diterapkan pada ruang sosial kampung. Tatanan rumah penduduk yang saling berhadapan di utara dan selatan adalah usaha manusia untuk membentuk ruang sosial. Ruang sosial sangat diperlukan sebagai wujud kodrat manusia yang saling membutuhkan satu sama lain. Jalan kampung adalah ruang sosial dan merupakan pemaknaan manusia sebagai makhluk sosial.

Pada lokasi di sekitar penelitian arah hadap rumah mayoritas memakai sumbu Utara-Selatan. Namun, sumbu arah Utara - Selatan tersebut mengalami penyimpangan ke arah kanan (Gambar 2). Hal ini dipengaruhi oleh bentukan sungai Kali Mas yang menjadi acuan pembentukan jalan arteri yang pada masa pemerintahan Hindia Belanda. Jalan-jalan arteri tersebut lambat laun mulai menggeser peranan sungai sebagai sarana transportasi perdagangan di masa sebelum kolonialisme memasuki kota Surabaya (Gambar 1).

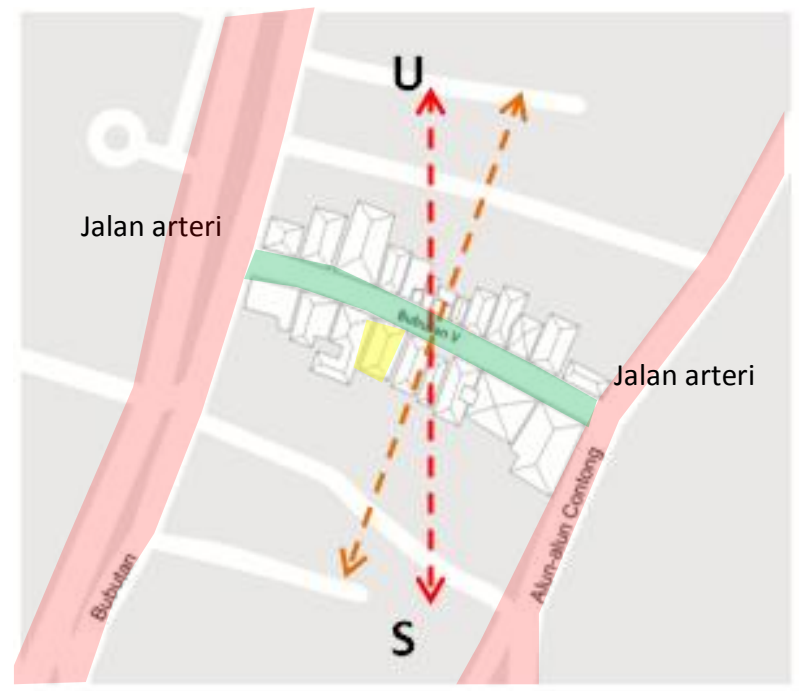

Gambar 2. Pergeseran sumbu Utara-Selatan akibat pengaruh sungai Kali Mas

\subsection{Telaah Rumah Kolonial}

Rumah kolonial yang berkembang di Indonesia memiliki 6 tipe, Nix, T [1994:268]; Indische Empire Style, Voor 1900, NA 1900, Romantiek, Tahun 1915-an (perpaduan NA 1900 dan Romantiek); dan Tahun 1930-an (pengaruh Amsterdam School dan $D e$ Stijl). Sebuah rumah kolonial yang akan dijadikan sebagai sampel yaitu rumah nomor 11 di bubutan gang V. Wujud fisik bangunan ini jika ditinjau dari teori Nix, mengacu pada tipe Voor 1900. Tipe rumah ini merupakan tipe yang paling banyak ditemukan di Kampung Bubutan. Pengaruh Voor 1900 yang berkembang pada pertengahan abad ke-19 ada pada detail tampak seperti kolom besi cor berukuran ramping, denah yang simetris, teras yang terbuka, pagar besi, teritisan. Rumah bapak Tedjo di jalan Bubutan V nomor 11 ini berdiri pada tahun 1909 dan masih terawat dengan baik (Gambar 3). 

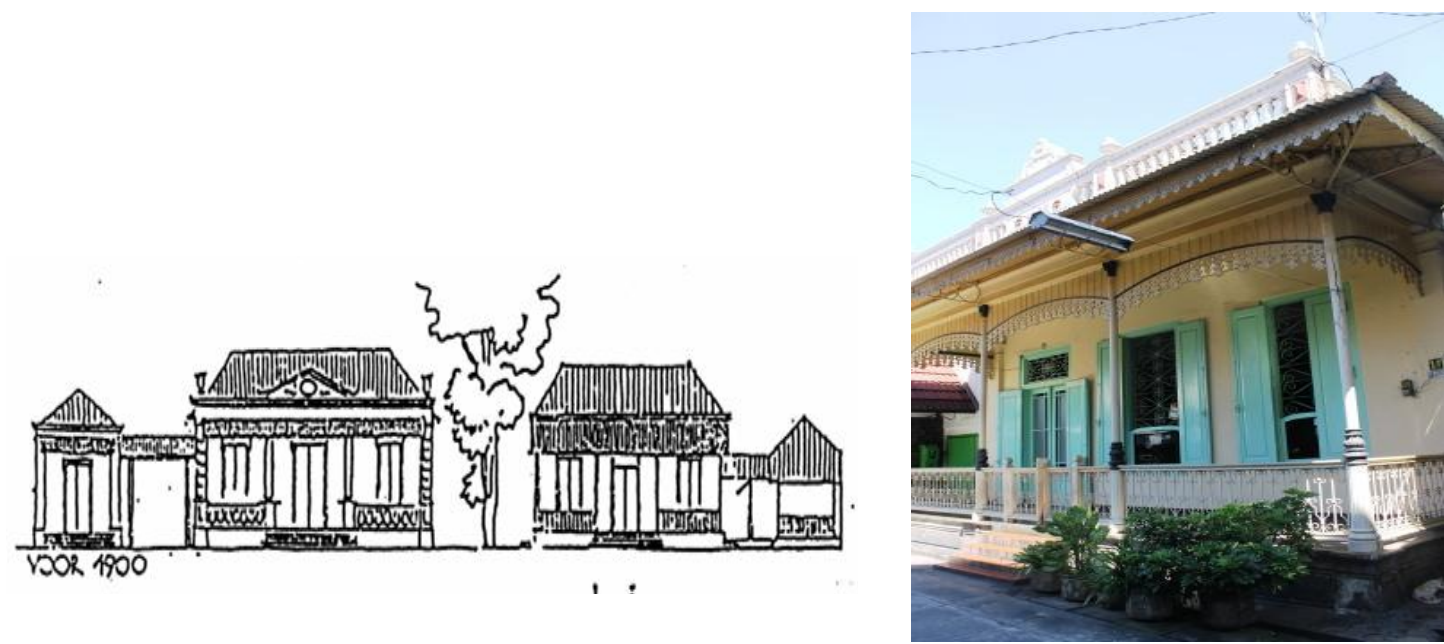

Gambar 3. Perbandingan tipe rumah Voor 1900 Nix, T (1994); rumah bapak Tedjo

Telaah rumah dibagi dalam dua tahap, tahap awal mencari pengaruh budaya Jawa dan Kolonial dari wujud fisik rumah, dan tahap selanjutnya menelusuri fungsi kegiatan dan makna dalam budaya Jawa. Tabel 1 menjelaskan bagaimana unit-unit amatan pada rumah dihubungkan dengan ada/tidaknya pengaruh dari arsitektur Jawa dan arsitektur Kolonial.

\section{Tabel 1. Telaah Arsitektur Jawa - Kolonial berdasarkan Unit Amatan Rumah}

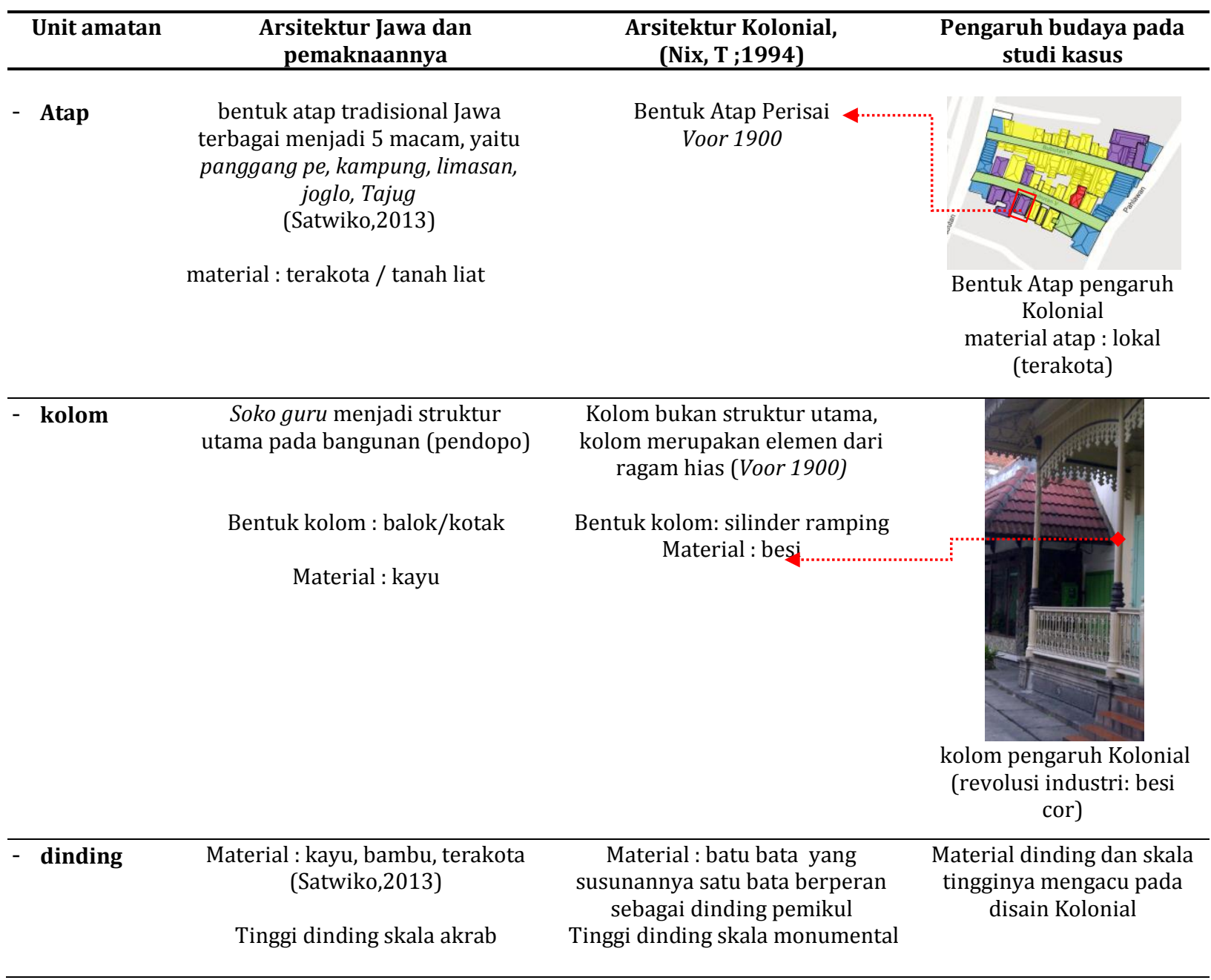


Lanjutan Tabel 1. Telaah Arsitektur Jawa-Kolonial berdasarkan Unit Amatan Rumah

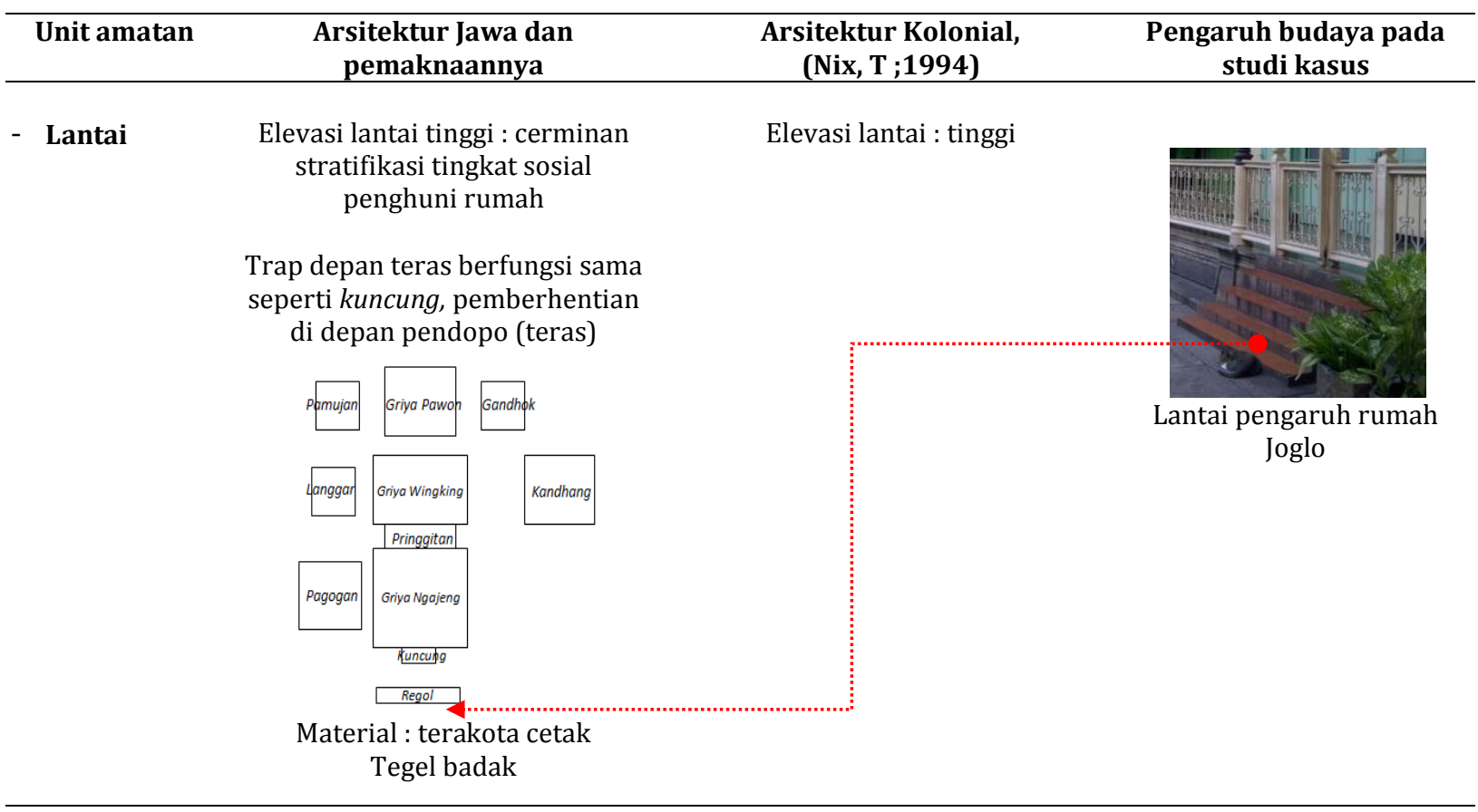

- Pintu-

Bukaan jendela relatif kecil (Satwiko,2013)

daun jendela memiliki jalusi dengan bukaan ke samping Material : kayu

Pintu terletak pada sumbu tengah tampak, jendela di kanan - kirinya

Tinggi pintu : skala akrab

Bukaan jendela lebar

Daun jendela tanpa jalusi Bukaan ke samping

Material : kayu dan kaca Penempatan pintu di samping

Tinggi pintu : skala monumental

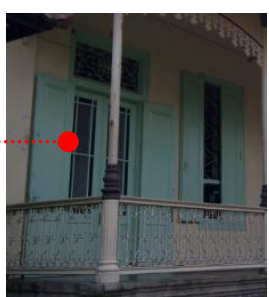

Bentuk dan tatanan : Pengaruh kolonial

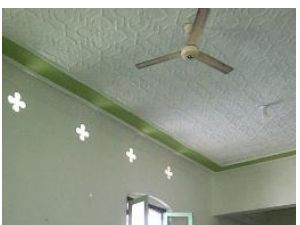

Plafon pengaruh Kolonial dengan pemakaian bahan eternit cetak

Tanpa plafon, konstruksi atap diekspos sebagai elemen estetika interior (Satwiko,2013)
Permanen, pengaruh Kolonial

Bangunan permanen, memiliki pondasi yang tertanam dalam tanah dan struktur batubata sebagai dinding pemikul

\begin{tabular}{|c|c|c|}
\hline $\begin{array}{l}\text { - struktur } \\
\text { bangunan }\end{array}$ & $\begin{array}{l}\text { Knock down, dapat dibongkar } \\
\text { pasang } \\
\text { Material: rangka kayu }\end{array}$ & $\begin{array}{c}\text { Bangunan permanen, memilik } \\
\text { pondasi yang tertanam dalam } \\
\text { tanah dan struktur batubata } \\
\text { sebagai dinding pemikul }\end{array}$ \\
\hline 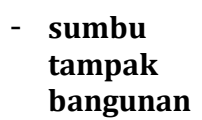 & $\begin{array}{l}\text { Tampak memiliki sumbu simetri } \\
\text { di tengah }\end{array}$ & $\begin{array}{l}\text { Voor } 1900 \text { : tampak simetris } \\
\text { NA } 1900 \text { : tampak asimetris }\end{array}$ \\
\hline
\end{tabular}

Voor 1900 : tampak simetris NA 1900 : tampak asimetris 
Lanjutan Tabel 1. Telaah Arsitektur Jawa-Kolonial berdasarkan Unit Amatan Rumah

\begin{tabular}{lccc}
\hline Unit amatan & $\begin{array}{c}\text { Arsitektur Jawa dan } \\
\text { pemaknaannya }\end{array}$ & $\begin{array}{c}\text { Arsitektur Kolonial, } \\
\text { (Nix, T ; 1994) }\end{array}$ & $\begin{array}{c}\text { Pengaruh budaya pada } \\
\text { studi kasus }\end{array}$ \\
\hline $\begin{array}{l}\text { ornamen } \\
\text { atap }\end{array}$ & & $\begin{array}{c}\text { Voor 1900, dengan geveltoppen } \\
\text { pada kemuncak } \\
\text { Material : beton dan batubata }\end{array}$ & \\
& & & $\begin{array}{c}\text { Ornamen atap pengaruh } \\
\text { Kolonial }\end{array}$ \\
\hline
\end{tabular}

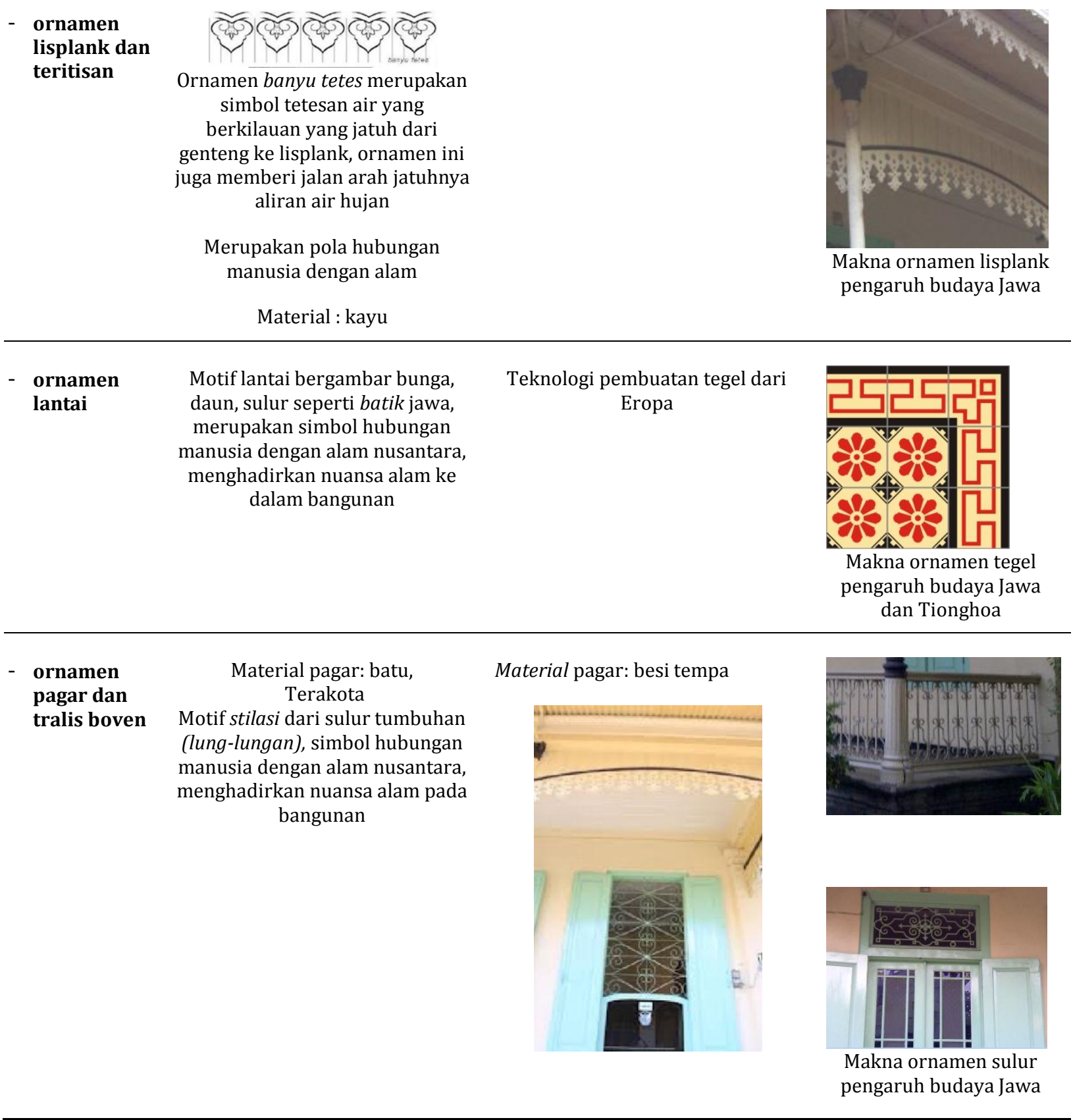

Hasil telaah rumah tahap pertama pada studi kasus rumah tipe Voor 1900 milik bapak Tedjo, didapatkan bahwa pengaruh arsitektur kolonial ditemukan pada bentuk 
atap perisai, struktur dinding satu bata yang berfungsi sebagai dinding pemikul, pemakaian bahan besi cor pada kolom, pagar, teralis, ruang dalam memiliki plafon, bukaan pintu dan jendela yang relatif lebar dan berkesan monumental, serta adanya onamen atap geveltoppen di bagian atas bangunan. Sedangkan unsur pengaruh budaya Jawa yang dapat ditemukan pada studi kasus adalah; pemakaian lantai tegel, dan ornamentasi bangunan yang mengandung makna alam di jawa seperti keindahan bunga, daun, akar, tetesan air (banyu tetes), kain batik, yang dibentuk dalam susunan stilasi.

Tahapan kedua akan dilakukan pemaknaan lebih mendalam pada pengaruh budaya Jawa. Fungsi-fungsi ruang pada studi kasus akan menjadi unit amatannya. Kegiatan dan aktifitas penghuni disandingkan dengan fungsi yang ada pada tatanan organisasi ruang pada omah Jowo, sekaligus mencari pemaknaan simbolis tentang pola hubungan manusia dalam budaya Jawa.

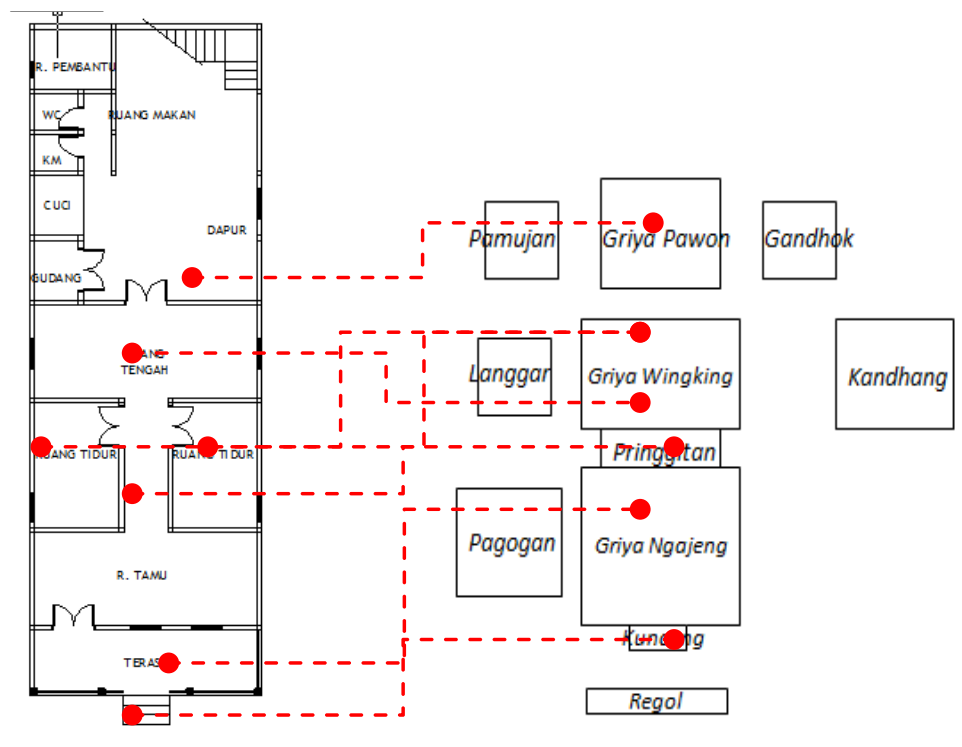

Gambar 4. Perbandingan Denah Studi Kasus dengan Tatana Omah Jowo

(Sumber: Tatanan Omah Jowo : Primbon Jawa Pandhita Sabda Nata [1975] dalam Prijotomo, 1999)

Fungsi-fungsi kegiatan dalam tatanan omah jowo akan dikonversikan pada studi kasus berdasarkan kesamaan jenis aktivitas (fungsi) pada rumah (Tabel 2). Tabel 2 sekaligus menjelaskan bagaimana makna simbolis dalam budaya Jawa berdasarkan unitunit amatan pada rumah.

Tabel 2. Telaah Arsitektur Jawa - Kolonial berdasarkan Fungsi Kegiatan

\begin{tabular}{|c|c|c|c|}
\hline Unit amatan & Fungsi ruang pada studi kasus & $\begin{array}{c}\text { Tata letak } \\
\text { Arsitektur Jawa } \\
\end{array}$ & $\begin{array}{c}\text { Makna simbolis budaya } \\
\text { Jawa }\end{array}$ \\
\hline 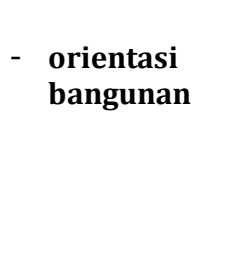 & $\begin{array}{c}\text { Arah hadap : utara } \\
\text { Menghadap ke jalan kampung }\end{array}$ & $\begin{array}{l}\text { Utara dijaga oleh batara Wishnu, } \\
\text { yang bertugas memelihara dan } \\
\text { melindungi manusia }\end{array}$ & $\begin{array}{l}\text { Manusia tunduk pada Alam } \\
\text { (Hamemayu hayuning } \\
\text { bawana) } \\
\text { manusia sebagai makhluk } \\
\text { sosial, membentuk ruang } \\
\text { sosial di depan rumahnya } \\
\text { Rukun agawe santoso }\end{array}$ \\
\hline $\begin{array}{l}\text { undakan } \\
\text { depan teras }\end{array}$ & $\begin{array}{l}\text { ruang peralihan untuk } \\
\text { memasuki wilayah teras }\end{array}$ & $\begin{array}{c}\text { Kuncung, sebagai penghubung } \\
\text { pintu masuk ke pendopo } \\
\text { Dapat pula berfungsi sebagai } \\
\text { regol, pintu gerbang }\end{array}$ & $\begin{array}{c}\text { Sikap menghargai } \\
\text { /menghormati orang lain, } \\
\text { tepa slira } \\
\text { Bersifat publik }\end{array}$ \\
\hline
\end{tabular}




\begin{tabular}{|c|c|c|c|}
\hline - teras & $\begin{array}{l}\text { Ruang untuk menerima tamu } \\
\text { sementara }\end{array}$ & $\begin{array}{c}\text { Pendhapa (griya ngajeng), ruang } \\
\text { untuk menerima dan menjamu } \\
\text { tamu }\end{array}$ & $\begin{array}{c}\text { Sikap menghargai } \\
\text { /menghormati orang lain, } \\
\text { tepa slira } \\
\text { Bersifat semi privat }\end{array}$ \\
\hline Unit amatan & Fungsi ruang pada studi kasus & $\begin{array}{c}\text { Tata letak } \\
\text { Arsitektur Jawa }\end{array}$ & $\begin{array}{l}\text { Makna simbolis budaya } \\
\text { Jawa }\end{array}$ \\
\hline - ruang tamu & $\begin{array}{l}\text { Ruang untuk menerima tamu } \\
\text { Ruang untuk melakukan kegiatan } \\
\text { sosial budaya seperti slametan } \\
\text { dengan masyarakat sekitar }\end{array}$ & $\begin{array}{c}\text { Pringgitan tempat untuk } \\
\text { menerima dan menjamu tamu } \\
\text { ruang untuk melakukan kegiatan } \\
\text { sosial dengan masyarakat sekitar }\end{array}$ & $\begin{array}{c}\text { manusia sebagai makhluk } \\
\text { sosial (Rukun agawe } \\
\text { santoso, gotong royong) } \\
\text { yang ingin berbagi rasa } \\
\text { syukur kepada sesama } \\
\text { Bersifat semi privat }\end{array}$ \\
\hline - ruang tidur & $\begin{array}{l}\text { Ruang untuk melakukan aktifitas } \\
\text { pribadi pemilik rumah }\end{array}$ & $\begin{array}{l}\text { Senthong (dalem), ruang pribadi } \\
\text { pemilik rumah }\end{array}$ & $\begin{array}{c}\text { Manusia sebagai } \\
\text { individual (sumeleh) } \\
\text { pasrah, menyerahkan diri } \\
\text { Bersifat privat }\end{array}$ \\
\hline $\begin{array}{ll}\text { - } & \text { ruang } \\
\text { tengah }\end{array}$ & $\begin{array}{c}\text { Ruang untuk melakukan kegiatan } \\
\text { bersama keluarga }\end{array}$ & $\begin{array}{l}\text { griya wingking, ruang pribadi } \\
\text { pemilik rumah }\end{array}$ & Bersifat privat \\
\hline - dapur & Kegiatan memasak & Pawon, ruang memasak & Bersifat semi privat \\
\hline
\end{tabular}

Dari amatan jenis aktifitas dalam hunian studi kasus, terdapat kesamaan fungsi ruang dalam tatanan omah Jowo. Penggunaan ruang teras merupakan pendhopo, ruang tamu dapat juga dikategorikan sebagai pendhopo dan pringgitan, ruang tidur merupakan senthong, ruang keluarga merupakan dalem, ruang dapur merupakan pawon. Beberapa ruang-ruang lain yang tidak teridentifikasi seperti; ruang pembantu, KM/WC, gudang, ruang cuci, adalah ruangan tambahan dari tuntutan kebutuhan penghuni dan merupakan gambaran tingkat sosial ekonomi yang tinggi. Rumah bapak Tedjo merupakan rumah yang ideal, karena sudah mewadahi fungsi minimal pada omah jowo seperti yang disampaikan oleh Prijotomo [1999]. Bahwa rumah jawa yang ideal, minimal memiliki ruang sedikitnya meliputi regol, pendhopo, pringgitan, dalem, gandhok, pawon.

\section{Kesimpulan}

Bentuk pola pemukiman di kampung Bubutan dengan karakter jalan arteri searah dengan Utara-Selatan dan arah hadap rumah yang dominan Utara-Selatan, dipengaruhi oleh tiga aspek. Yang pertama adalah keberadaan sungai Kali Mas sebagai potensi alamiah yang menciptakan tren perdagangan dari arah utara (pelabuhan) ke arah selatan (tengah kota), yang kedua aspek tradisi perdagangan yang menjadi ciri khas kota pesisir, sehingga membentuk jalan arteri kota. Dan yang ketiga adalah aspek budaya Jawa yang mempercayai mitos Mancapat bahwa tunduk pada kekuatan alam dikuasai oleh dewa Wishnu dan penguasa laut Selatan akan mendapatkan keselamatan kehidupan yang lebih baik. yang ditemukan pada arah hadap hunian utara dan selatan.

Wujud akulturasi budaya Jawa dan Kolonial jika ditinjau dari aspek fisik rumah adalah: pengaruh arsitektur Kolonial pada studi kasus lebih mengarah pada teknologi bahan dan konstruksi bangunan. Pengaruh Kolonial tersebut terdapat pada bentuk atap, teknologi struktur bangunan, teknologi besi cetak pada kolom dan ornamen, ukuran (skala) pintu dan jendela, teknologi besi tempa, dan sumbu asimetris pada tampak bangunan. Sedangkan pengaruh arsitektur Jawa lebih kuat mempengaruhi ornamen pada bangunan. Aplikasi ornamen bersimbol bunga, sulur (lung-lungan), akar merupakan konsep dari hubungan menghargai alam nusantara. Keindahan alam 
nusantara dihadirkan dalam bentuk ornamen pada pagar, teralis, teritisan, dan pola lantai.

Wujud akulturasi budaya Jawa dan Kolonial jika ditinjau dari aspek fungsi dan makna ruang, membuktikan bahwa hunian pada studi kasus masih memegang nilainilai budaya Jawa yang dituangkan dalam kegiatan yang menggunakan ruang. Ruangan tersebut yaitu; teras (pendhopo), ruang tamu (pringgitan), ruang tidur (senthong), ruang tengah (dalem), dan dapur (pawon). Pemaknaan pada ruang hunian merupakan nilai hubungan manusia dengan alam, manusia sebagai makhluk sosial, dan manusia sebagai individu. Pengaruh akulturasi Arsitektur Kolonial dan Jawa pada pola permukiman dan hunian rumah tinggal merupakan lokalitas budaya arsitektur yang menjadi kearifan lokal untuk keberlanjutan arsitektur nusantara.

\section{Daftar Pustaka}

Darjosanjoto, E. 2005. 'Kembang Jepun': Jalan Dominan Kota Surabaya. Jurnal Dimensi Teknik Arsitektur. XXXIII (1) : 143-152.

Fauzi, B. 2011. Memahami Relasi Konsep Fungsi, Bentuk Dan Makna Arsitektur Rumah Tinggal Masyarakat Kota Pesisir Utara Di Kawasan Jawa Timur (Kasus Studi Rumah Tinggal Di Kampung Karangturi Dan Kampung Sumber Girang, Lasem). DIMENSI (Journal of Architecture and Built Environment). XXXVIII(2): 79-88.

Fauzy, 2012. Konsep Kearifan Lokal dalam Arsitektur Rumah Tinggal Masyarakat Kota Pesisir Utara Jawa. Lembaga Penelitian dan Pengabdian kepada Masyarakat.

Frick, H. 2010. Pola Struktural dan Teknik Bangunan di Indonesia. Yogyakarta: Kanisius.

Hartono, S. \& Handinoto. 2006. 'Arsitektur Transisi' di Nusantara dari Akhir Abad 19 ke Awal Abad 20. (Studi Kasus Komplek Bangunan Militer di Jawa pada Peralihan Abad 19 ke 20). Dimensi Teknik Arsitektur . XXXIV (2): 81-92.

Koentjaraningrat, 1981. Pengantar Ilmu Antropologi, Jakarta: Rinerka Cipta.

Prijotomo, J. 1999. Griya dan Omah Penelusuran Makna dan Signifikasi di Arsitektur Jawa. Dimensi Teknik Sipil. XXVII : 30-36.

Prijotomo, J. 2002. Serat Balewarna : Jawa Menolak Jawa Kolonialisasi ataukah Rasionalisasi Pengetahuan Jawa? Dimensi Teknik Arsitektur. XXX (1) : 63.

Ronald, A. 2005. Nilai-Nilai Arsitektur Rumah Tradisional Jawa. Yogyakarta : UGM Press.

Soenarjo. 2006. Mana Soerabaia Koe, Mengais Butiran Mutiara Masa Lalu. Surabaya: Pustaka Eureka.

Widodo, D. I. 2013. Hikajat Soerabaia Tempo Doeloe. Surabaya: Dukut Publishing. 